\title{
SODIUM AZIDE INDUCED MORPHOLOGICAL AND MOLECULAR CHANGES IN PERSIMMON (DIOSPYROS LOTUS L.)
}

\author{
ZUZANA KOCHANOVÁ ${ }^{1,2 *}$, KATARÍNA RAŽNÁ ${ }^{1}$, ELENA ZURIAGA³, MARIA LUISA BADENES ${ }^{3}$, \\ JÁN BRINDZA ${ }^{1}$
}

\author{
${ }^{1}$ Slovak University of Agriculture, Nitra \\ ${ }^{2}$ Institute of Botany, Slovak Academy of Sciences, Bratislava \\ ${ }^{3}$ Instituto Valenciano de Investigaciones Agrarias (IVIA), Valencia
}

KOCHANOVÁ, Z. - RAŽNÁ, K. - ZURIAGA, E. - BADENES, M.L.: Sodium azide induced morphological and molecular changes in persimmon (Diospyros lotus L.). Agriculture (Polnohospodárstvo), vol. 58, 2012, no. 2, pp. 57-64.

Persimmon Diospyros lotus L. is an underutilized species, used as rootstock for Japanese persimmon (Diospyros kaki Thunb.) in many European countries. It has a potential for ornamental uses due to its diploid genome that suggests an easy mutation induction. This study was aimed at unravelling the effects of mutagenic sodium azide (in concentrations of $0.1 \%$ and $0.5 \%$ ) on morphological characters (plant height, maximal leaf blade length, maximal leaf blade width and leaf petiole length) and molecular relations of treated accessions, based on AFLP (amplified fragment length polymorphism). In the M1 generation, the analysed characters of two-year old plants differed among the treatments. Sodium azide influenced persimmon stem and leaves in the opposite way, with increase up to $31.57 \%$ in plant height and decrease up to $30.33 \%$ in leaf petiole length. Changes in morphological characters were significant, that implies the importance of azide influence on the persimmon. Most genotypes treated with $0.1 \%$ azide were without significant differences among them and clustered together. The results suggest that the higher azide concentration of $0.5 \%$ is more suitable for persimmon seeds azide treatment to form genotypes, significantly different from the control, at the molecular level.

Key words: AFLP, Diospyros lotus, mutagen, persimmon, sodium azide

Persimmon (Diospyros lotus L.), a deciduous tree from the Ebenaceae family, is a relatively neglected and underutilized species. Diospyros lotus is used as a rootstock for Japanese persimmon (Diospyros kaki Thunb.) in Central and Western Europe (Messaoudi et al. 2009; Samadi et al. 2009). Diospyros lotus originates from East Asia and is still extended in countries of South and West Asia, for instance in Afghanistan (Samadi et al. 2009) and Iran (Khoshbakht \& Hammer 2006) where it is part of wild flora.

The fruit of Diospyros lotus is full of seeds, less suitable for consumption and smaller than the fruit of Japanese persimmon, well-known for its delicious taste (Grygorieva et al. 2009). Persimmon Diospyros lotus is a diploid plant, in contrast with Japanese per- simmon, that is usually hexaploid (Tao et al. 2009). Recent research on Diospyros lotus fruits was focused mainly on studies of biochemical properties (Ayaz \& Kadioglu 1997) and antioxidant (Nabavi et al. 2009), antiproliferative (Loizzo et al. 2009), analgethic, antiinflammatory and heparoprotective (Said et al. 2009) effects.

Previous studies showed that RAPD (random amplified polymorphic DNA) technology is adequate for fingerprinting persimmon and the data are consistent with persimmon's hypothetical origins, adaptation of history and classification by isozymes or pomological traits (Badenes et al. 2003). The potential of RAPD analysis for persimmon identification has been discussed in Luo et al. (1995). Genetic diversity among

*Corresponding author:

RNDr. Zuzana Kochanová, PhD., Institute of Botany, Slovak Academy of Sciences, 84523 Bratislava, Dúbravská cesta 9, Slovak Republic. E-mail: zuzana.kochan@gmail.com 
different persimmon cultivars including those collected in the European survey as well as Japanese cultivars was distinguished by microsatellite markers (Naval et al. 2010) revealing genetic relationship among Japanese and Chinese genotypes (Chen et al. 2011).

Diospyros lotus has a high potential for future extended use beyond rootstock, as element of gardens and parks (Li et al. 2006; Gullino et al. 2009; Irmak \& Yilmaz 2008). Among the different strategies available, sodium azide is a mutagenic agent that causes change at morphological base being a good alternative for increasing diversity in this species for its ornamental use. However, the effect of sodium azide as a mutagenic factor on changes of morphometrical characters of Diospyros lotus is not known. This study is aimed at unravelling the effects of different concentrations of the mutagenic sodium azide on morphological characters of Diospyros lotus seedlings and molecular changes analysed by AFLP techniques.

\section{MATERIALS AND METHODS}

\section{Plant material, mutagen treatment and characters measured}

The plant material consisted of seedlings from different Diospyros lotus L. genotypes maintained at the Mlyňany Arboretum in Slovakia. The trees were 30years old and were imported to the Mlyňany Arboretum from China. Seeds were kept in a greenhouse for a period of one month, later the seeds were soaked in a solution of sodium azide $\left(\mathrm{NaN}_{3}, 99 \%\right.$, Aldrich) for 24 hours. Two treatments were performed: $0.1 \%$ sodium azide and $0.5 \%$ sodium azide, plus a control with no treatment. Each treatment consisted of 50 seeds. After the treatment the seeds germinated and were planted in the field. One-year old plants (in the spring 2008) were grafted by own scions to accelerate the development.

Samples were collected from two-year old plants in the summer 2009. A total of 18 persimmon accessions (Diospyros lotus L.) were selected for analyses, three controls, nine accessions from the $0.1 \%$ treatment and six from the $0.5 \%$ treatment. For morphometrical analyses, 10 leaves, from $6^{\text {th }}$ to $10^{\text {th }}$ leaf from the distal part of a twig, were collected from each of 18 accessions. Leaves $1^{\text {st }}-3^{\text {rd }}$ from the distal part of a twig were used for DNA isolation and molecular analyses. The characters measured were plant height $(\mathrm{mm})$, maximal leaf blade length $(\mathrm{mm})$, maximal leaf blade width $(\mathrm{mm})$, and leaf petiole length $(\mathrm{mm})$.

\section{Generation of molecular data}

DNA isolation and quantification. $50 \mathrm{mg}$ of leaves were homogenised in liquid nitrogen and stored at $-80^{\circ} \mathrm{C}$ until the DNA isolation was performed. A commercial kit (Invisorb ${ }^{\circledR}$ Spin Plant Mini Kit, Invitek) was used for DNA isolation. DNA concentration was quantified using a spectrophotometry NanoDrop ND-1000 (NanoDrop Technologies, Wilmington, Germany).

AFLP analyses. The AFLP technique provides a very powerful DNA fingerprinting technique for DNAs of any origin or complexity. The method allows the specific co-amplification of high numbers of restriction fragments (Vos et al. 1995). The AFLP analysis was carried out according to Vos et al. (1995), modified as follows: $150 \mathrm{ng}$ of each DNA sample was digested by the restriction enzymes EcoRI and Tru9I. Ligation was performed using $1 \mathrm{X}$ T4 ligase buffer, $1 \mathrm{U}$ of T4 ligase (Roche, Basel, Switzerland), 40 pmol of Mse adaptor, and 4 pmol Pst adaptor, incubating at $20^{\circ} \mathrm{C}$. After ligation, the reaction mixture was diluted 1:5 in Tris-EDTA (TE) buffer.

For the pre-selective amplification, a $5 \mathrm{ml}$ aliquot from the DNA dilution was added to a $25 \mathrm{ml}$ solution containing $2.5 \mathrm{ml}$ of $10 \times$ buffer, $0.5 \mathrm{ml}$ of primer PstA ( $10 \mathrm{mmol} / \mathrm{l}), 0.5 \mathrm{ml}$ of primer MseC (10 mmol/1), $1.0 \mathrm{ml}$ of dNTPs $(10 \mathrm{mmol} / \mathrm{l})$, and 0.8 units of Taq polymerase (Roche, Basel, Switzerland).

After pre-amplification, DNA was diluted again 1:10 in TE buffer. Selective amplification employed three selective nucleotides on each fluorescently labelled primer. Four selective combinations of primers were used: (NED)Pst + AGC and Mse + CTA; (VIC)Pst $+\mathrm{ACG}$ and Mse + CTA; (FAM)Pst + ACA and Mse + CC; (PET)Pst + AGG and Mse + CC. DNA fragments were separated in the ABI Prism 3130 Genetic Analyzer (Applied Biosystems, Foster City, CA, USA).

\section{AFLP data analysis}

The AFLP fragments were scored as binary traits ( 1 = present, $0=$ absent) using GeneMapper v. 4 software. Cluster analysis and estimates of genetic distances - pairwise genetic similarities were estimated with the Jaccard coefficient $\mathrm{Jij}=\mathrm{a} /(\mathrm{a}+\mathrm{b}+\mathrm{c})$, where $a$ is the number of bands shared by $i$ and $j, b$ is the number of bands present in $\mathrm{i}$ and absent in $\mathrm{j}$, and $\mathrm{c}$ is the number of bands present in $\mathrm{j}$ and absent in $\mathrm{i}$. 
The resulting genetic similarity matrix was used to generate unweighted pair group method with arithmetic means (UPGMA) phenogram using the NTSYSpc2.0 software package. A principal coordinate analysis (PCA) based on the genetic similarity matrix was performed using the DCENTER and EIGEN algorithms of the NTSYSpc2.0 software package.

\section{Statistical evaluation}

Measured values were processed by software STATISTICA with Kruskal-Wallis test as non-parametric method for comparison of more independent groups. For molecular evaluation, presence (1) or absence (0) of alleles as outputs from the sequenator was determined for each primer to generate a binary matrix of data.

Jaccard coefficients of genetic relationship were used to evaluate genetic relations among the accessions. On the base of binary matrices dendrograms were created by the program Syntax (UPGMA). The experiments were realised in laboratories of the IVIA Research Institute in Valencia, Spain and at the Department of Genetics and Plant Breeding at the Slovak Agricultural University in Nitra, Slovakia.

\section{RESULTS AND DISCUSSION}

Influence of sodium azide on morphological characters of Diospyros lotus

In the M1 generation, one-year old persimmon (Diospyros lotus L.) plants, grown from azide-treated seeds, showed only small visual differences related to stem and leaf morphological characters, in contrast to the two-year old plants, whose character differences during the treatments were analysed.

In contrast with Sander and Muehlbauer (1977), who studied mutagenic effect of sodium azide and did not observe leaf aberrations on azide-treated plants of pea, results of the present study show stem and leaf changes on the persimmon plants. After the azide treatment of seeds, the persimmon plant height increased and the leaf blade width and leaf petiole length were reduced, in comparison with the control.

Previous morphological analysis of Diospyros lotus in the conditions of Slovakia showed following measured values of mature leaves: minimal-maximal leaf length (mm) 51.00-161.00; minimal-maximal leaf width (mm) 24.00-75.00 (Grygorieva et al. 2009). The values were lower, but approximately corresponded to values of the control variant, not treated with sodium azide, in this study: minimal-maximal leaf length (mm) 94.00-163.00; minimal-maximal leaf width (mm) 44.00-86.00. There were significant differences between control variant and the azide treated plants in most of the characters (Figure 1).

Significant changes in morphological characters were determined after treatment with sodium azide in comparison with the control, in plant height, leaf blade width and leaf petiole length, and the differences were not significant between the lower $(0.1 \%)$ and higher $(0.5 \%)$ azide concentrations. The only exception was the character leaf blade length that was significantly changed only at the higher azide concentration $(0.5 \%)$.

Sodium azide influenced growth of persimmon stems and leaves in the opposite way. While the stem character (plant height) was significantly increased after the azide treatments $(0.1 \% / 0.5 \%$ sodium azide concentration) $(31.57 \% / 20.81 \%)$, the characters leaf blade width $(-23.26 \% /-22.46 \%)$ and leaf petiole length $(-28.50 \% /-30.33 \%)$ were significantly decreased. Changes in leaf blade length were minimal, this character was increased slightly under $0.1 \%$ azide treatment (1.21\%), and was decreased slightly under $0.5 \%$ azide treatment $(-13.89 \%)$ (Figure 1$)$. Changes in morphological characters that were greater than $20 \%$ or $30 \%$ were significant and suggest the importance of azide influence on the growth parameters of persimmon (Diospyros lotus L.).

Prina and Favret (1983) induced morphological changes in barley using low azide concentrations $\left(5 \times 10^{-4}\right.$ and $\left.1 \times 10^{-3} \mathrm{M}\right)$. With regard to changes in crop performance due to chemical mutagen treatment, our results are supported by other studies on different plant species (Ahloowalia \& Maluszynski 2001; Al-Qurainy 2009), especially on related persimmon species (Jo et al. 2003; Yamane et al. 2009), although some controversy exists about the issue (Mitchell et al. 1992).

Sodium azide caused morphological changes in different plant species in previous studies. Treatment of barley seeds with sodium azide caused a delay in the seedlings growth (Ilbas et al. 2005). In the M2 generation the barley plant height was reduced (Pearson et al. 1975), which is not in accord with the results of present study on persimmon in M1 generation. The Eruca sati- 
$v a$ radicle and coleoptyle lengths were reduced with the increasing sodium azide concentrations (Khan \& Al-Qurainy 2009), similarly like the persimmon leaf blade width and leaf petiole length in the present study. On Pisum sativum plants after the sodium azide treatment morphological deformations (Sander \& Muehlbauer 1977) and dwarf growth (Divanli-Turkan et al. 2006) were observed. Morphological changes in plants induced with sodium azide are probably caused by inhibition of protein synthesis, DNA replication (Veleminsky \& Angelis 1987), polyphenoloxidase (Ozen et al. 2004) and nitrate reductase activity (Yamasaki \& Sakihama 2000), and reduction of respiration in young leaves (Stenlid 1949).

Effect of sodium azide on molecular variation in persimmon (Diospyros lotus L.)

Effect of sodium azide on persimmon (Diospyros lotus L.) was analysed at the molecular level by DNA polymorphism. Detected unique DNA fragments according to the primers used were 47, 30, 13 and 15 for FAM, NED, PET and VIC respectively. The percentage of polymorphic fragments was $69.3 \%, 66.3 \%, 76.8 \%$ and $17.6 \%$ for FAM, NED, PET and VIC, respective- ly. In a recent study on a related persimmon species (Diospyros kaki L.f.) a high degree of polymorphism was revealed among different cultivars (Maki et al. 2001).

Cluster analyses (Figure 2) showed a high variability among the samples studied (primer FAM - 17 clusters, primer NED - 15 clusters, primer PET - 17 clusters, primer VIC - 17 clusters). A minimum value of the Jaccard coefficient of genetic relationship was 0.165 for primer FAM, 0.171 for NED, 0.231 for PET and 0.226 for VIC. A maximal value of the Jaccard coefficient of genetic relationship for FAM was 0.979, for NED 0.971, for PET 0.929 and for VIC 0.943. The genotypes 10,13,14, 15 and 18 significantly differed from the other. They had in common the treatment of $0.5 \%$ azide, except from the genotype 10 , that was treated with $0.1 \%$ azide.

The UPGMA analyses provided a logical arrangement of relationships among the genotypes. The results of the four primers combinations were similar, but not identical. In all four combinations, the analyses showed formation of a central cluster of genotypes treated with $0.1 \%$ azide. The genotypes treated with $0.5 \%$ azide

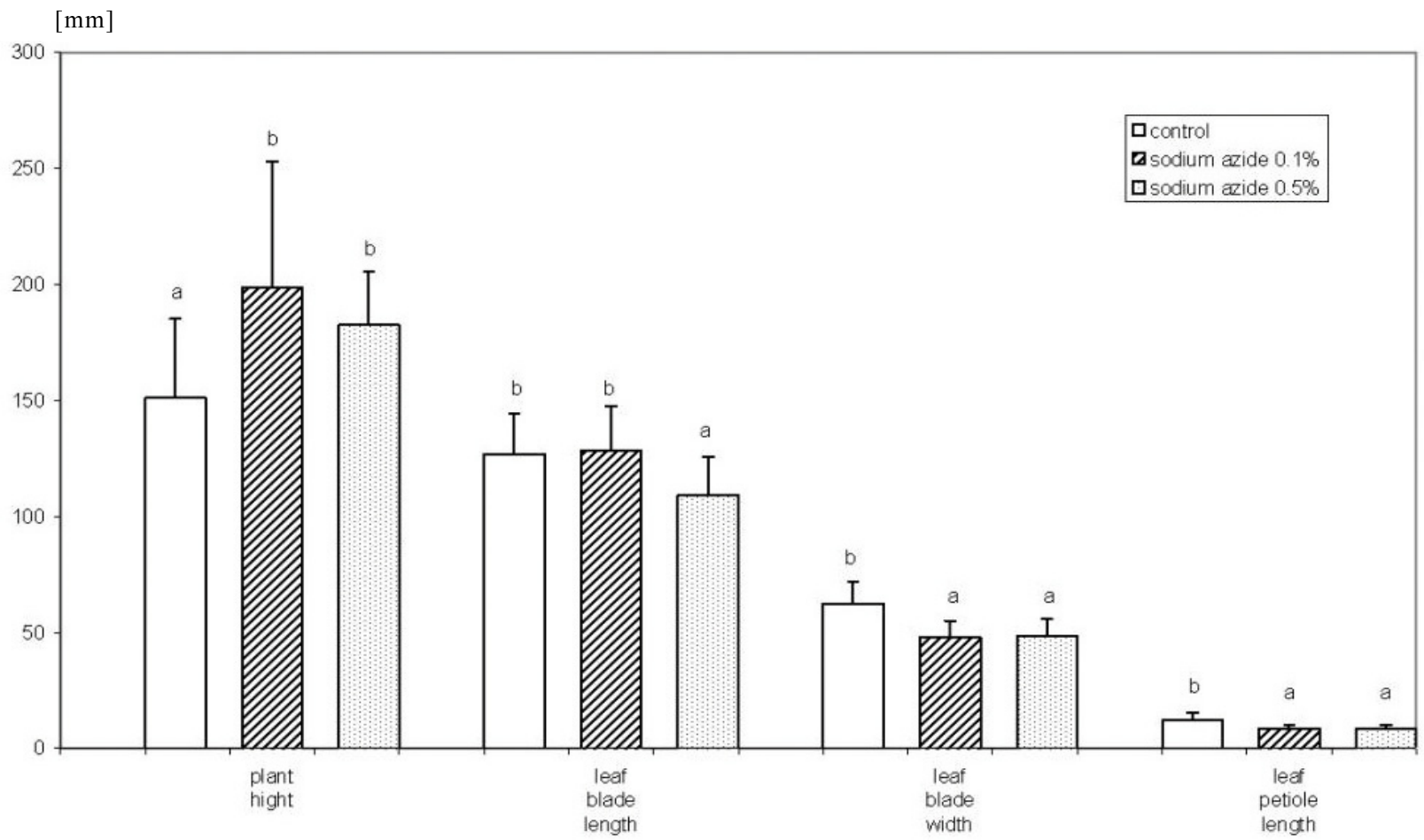

Figure 1. Different sodium azide concentrations effects on morphological characters in persimmon (Diospyros lotus L.) seedlings (data with standard deviation) 
were dispersed and some of them overlapped with the $0.1 \%$ group. Most of the observed polymorphisms were among analysed groups (control, $0.1 \%$ azide and $0.5 \%$ azide), and the differences among the groups were larger than among the genotypes in a group. This trait varies at different analyses on persimmon cultivars (Badenes et al. 2003; Yonemori et al. 2008). Of the three groups, the least significant differences among the genotypes in a group were observed in the $0.1 \%$ azide group.

Most of the $0.1 \%$ azide treated genotypes were gathered in a separated cluster which suggests that a lower azide concentration caused in all the genotypes similar genetic changes. The $0.5 \%$ azide treated genotypes did not create a separate cluster, but differed from each other. The results suggest that the higher azide concentration is more suitable for persimmon seeds azide treatment to form genotypes, significantly different from the control, at the molecular level.

After seed treatment with sodium azide, changes at the molecular level were expected. Due to sodium azide induced gene mutations in plants, higher tolerance to stress (Al-Qurainy \& Khan 2009) and resistance against pathogens (Kiruki et al. 2006; MolinaCano et al. 2003) were obtained.

To describe genotype changes at the molecular level, different methods like RAPD (Yamagishi et al. 2005), IRAP (inter-retrotransposon amplified polymorphism), REMAP (retrotransposon-microsatellite amplified polymorphism) (Guo et al. 2006), RFLP (restriction fragment length polymorphism) (Maki et al. 2001) were used in the past. RAPD markers clarified the phenetic relationship among species and subspecies of Diospyros: D. lotus, D. lotus subsp. glabra

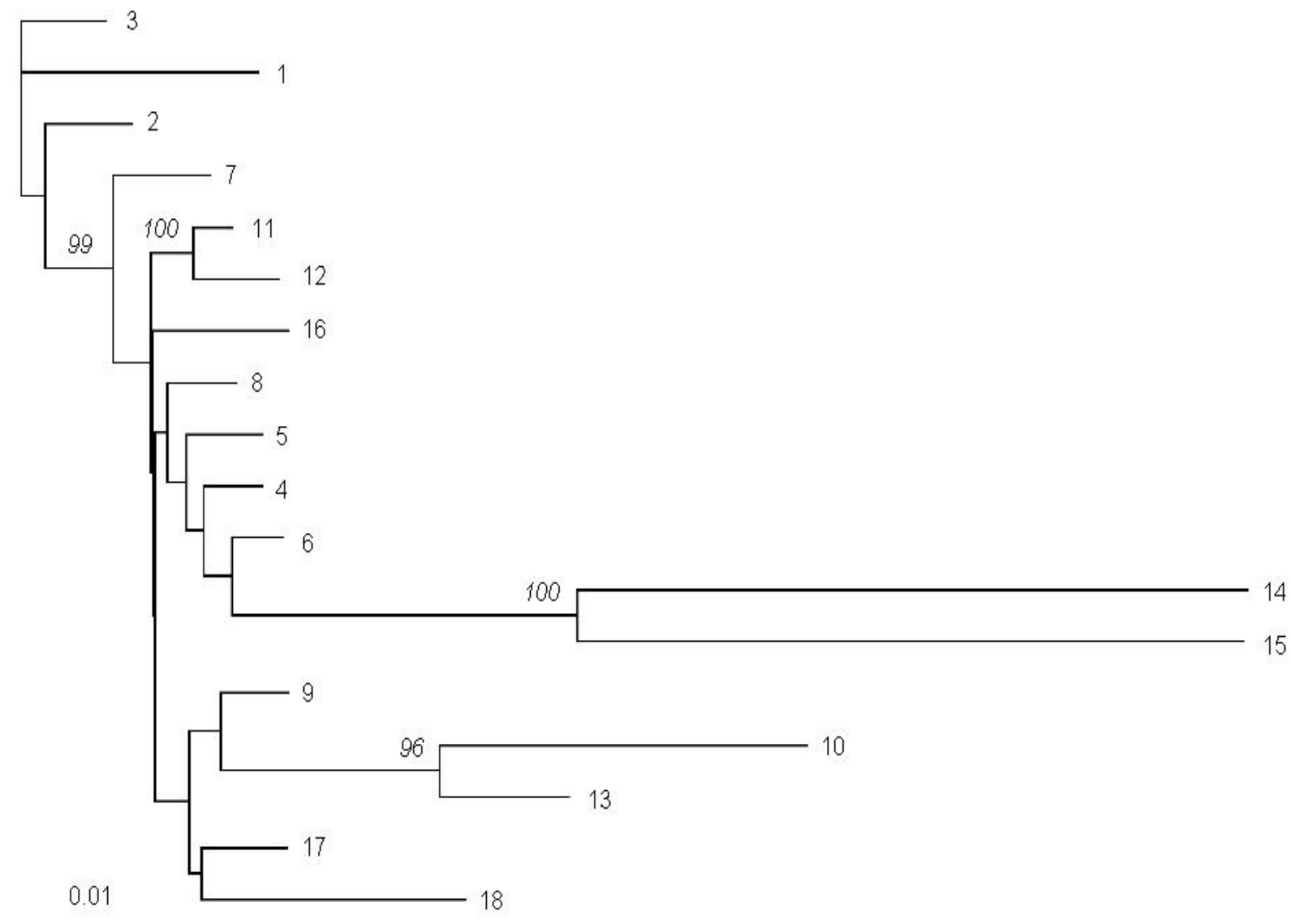

Legend: Samples: 1-3: control - genotypes not treated with sodium azide; 4-12: genotypes treated with sodium azide at the concentration of $0.1 \% ; 13-18$ : genotypes treated with sodium azide at the concentration of $0.5 \%$

Figure 2. Dendrogram of analyzed genotypes of Diospyros lotus L., constructed upon UPGMA analysis, using all the primers 
and D. taitoensis formed one group (lotus group), and persimmon was related in order of closeness to the $l o$ tus group, D. oleifera, and D. rhombifolia (Yamagishi et al. 2005). Analyses based on SRAP (sequence-related amplified polymorphism) showed that Chinese and Japanese pollination-constant and non-astringent (PCNA) persimmons had different genetic background (Guo \& Luo 2006). IRAP and REMAP analysis of genetic relationships revealed that the Japanese and Chinese genotypes and related species were distinctly separated (Guo et al. 2006). The UPGMA dendrogram of the IRAP analyses grouped mutant persimmon plants tightly with each other and meanwhile with standard cultivar, for IRAP could distinguish the micromutations (Du et al. 2011).

For analyses in the present study AFLP-PCR was chosen, often used for persimmon analyses to study genetic relationships among cultivars (Kanzaki et al. 2000, Cho et al. 2007), as very sensitive and suitable for evaluation of genetic stability (Prado et al. 2007) and recommended for distinguishing the control and mutant plants (Al-Qurainy \& Khan 2009).

Sodium azide causes a higher frequency of mutations in hexaploid than in diploid plants due to duplicative loci, masking the effect of mutations in an individual locus of hexaploids. As a result more than hundred times more mutant manifestations can be obvious on diploid plants, in comparison with hexaploid plants (Rines 1985). For this reason a neglected species persimmon (Diospyros lotus L.), that is grown as a diploid, has an excellent potential for breeding and utilization using sodium azide, as the results of the present study suggest.

\section{CONCLUSION}

Morphological characters were significantly changed already in the M1 generation, for instance the plant height significantly increased and the leaf petiole length significantly decreased. Changes in morphological characters, that reached up to $30 \%$, were significant and suggest the importance of azide influence on the growth parameters of persimmon (Diospyros lotus L.).

The molecular analyses based on the AFLP showed differences in sodium azide treated accessions in comparison with the controls. The changes were more obvious after the treatment with the higher mutagen concentration. The results suggest that the higher azide concentration of $0.5 \%$ is more suitable for persimmon seeds to form genotypes, which are significantly different from the control, at the molecular level. According to our results, using the sodium azide as a mutagen agent can be recommended for further experiments to develop new forms of Diospyros lotus as a plant with a great ornamental potential.

\section{REFERENCES}

AHLOOWALIA, B.S. - MALUSZYNSKI, M. 2001. Induced mutation. A new paradigm in plant breeding. In Euphytica, vol. 118, 2001, no. 2, pp. 167-173. DOI: 10.1023/ A: 1004162323428

AL-QURAINY, F. 2009. Effects of sodium azide on growth and yield traits of Eruca sativa (L.). In World Applied Sciences Journal, vol. 7, 2009, no. 2, pp. 220-226.

AL-QURAINY, F. - KHAN, S. 2009. Mutagenic effects of sodium azide and its application in crop improvement. In World Applied Sciences Journal, vol. 6, 2009, no. 12, pp. 1589-1601.

AYAZ, A. - KADIOGLU, A. 1997. Changes in phenolic acid contents of Diospyros lotus L. during fruit development. In Journal of Agricultural and Food Chemistry, vol. 45, 1997, no. 7, pp. 2539-2541. DOI: 10.1021/jf960741c

BADENES, M. - GARCES, A. - ROMERO, C. - ROMERO, M. - ClAVE, J. - ROVIRA, M. - LLACER, G. 2003. Genetic diversity of introduced and local Spanish persimmon cultivars revealed by RAPD markers. In Genetic Resources and Crop Evolution, vol. 50, 2003, no. 6, pp. 579-585. DOI: $10.1023 / \mathrm{A}: 1024474719036$

CHEN, F.Y. - NI, H.Z. - HE, L.K. - WANG, Y. - LU, G.Y. - WANG, D.M. - REN, Z.C. 2011. Identification and genetic relationships analysis of some oriental persimmon (Diospyros kaki) and related species in Zhejiang province based on SSR analysis. In Journal of Fruit Science, vol. 22, 2011, no. 1, pp. 46-50.

CHO, D.H. - CHUN, I.J. - KWON, S.T. - SONG, Y.S. - CHOU, Y.D. 2007. Genetic relationships of Korean astringent persimmon varieties using AFLP analysis. In Korean Journal of Horticultural Science \& Technology, vol. 25, 2007, no. 2, pp. 114-118.

DIVANLI-TURKAN, A. - KHAWARI, K.M. - CIFTCI, C.Y. - OZCAR, S. 2006. Effects of mutagenic sodium azide $\left(\mathrm{NaN}_{3}\right)$ on in vitro development of four pea (Pisum sativum L.) cultivars. In International Journal of Agriculture \& Biology, vol. 8, 2006, no. 3, pp. 349-353.

DU, X.Y. - ZHANG, Q.L. - LI, B. - LENG, P. - ZHANG, M.D. - HUANG, J.M. - LUO, Z.R. 2011. Mutations identification based on IRAP analysis in Diospyros kaki cv. Damopan. In Journal of Fruit Science, vol. 22, 2011, no. 2, pp. 257-262.

GRYGORIEVA, O. - KLYMENKO, S. - BRINDZA, J. - KOCHANOVA, Z. - TOTH, D. - DEREVJANKO, V. - GRA- 
BOVECKA, O. 2009. Morphometrical analysis of Diospyros lotus population in the Mlyňany Arboretum, Slovakia. In Acta Horticulturae, 2009, no. 833, pp. 145-150.

GULlinO, P. - DEVECCHI, M. - LARCHER, F. 2009. The cultivation and ornamental uses of persimmon in Piedmontese gardens. In Acta Horticulturae, 2009, no. 833, pp. $83-88$.

GUO, D. - ZHANG, H. - LUO, Z. 2006. Genetic relationships of Diospyros kaki Thunb. and related species revealed by IRAP and REMAP analysis. In Plant Science, vol. 170, 2006, no. 3, pp. 528-533. DOI: 10.1016/j.plantsci.2005.10.006

GUO, D.L. - LUO, Z.R. 2006. Genetic relationships of some PCNA persimmons (Diospyros kaki Thunb.) from China and Japan revealed by SRAP analysis. In Genetic Resources and Crop Evolution, vol. 53, 2006, no. 53, pp. 1597-1603. DOI: 10.1007/s10722-005-8717-5

ILBAS, A.I. - EROGLU, Y. - EROGLU, H.E. 2005. Effects of the application of different concentrations of $\mathrm{NaN}_{3}$ for different times on the morphological and cytogenetic characteristics of barley (Hordeum vulgare L.) seedlings. In Journal of Integrative Plant Biology, vol. 47, 2005, no. 9, pp. 1101-1106. DOI: 10.1111/j.1744-7909.2005.00137.x

IRMAK, M.A. - YILMAZ, H. 2008. Determination of the usability of woody plant species in Tortum - Creek Watershed for functional and aesthetical uses in the respect of landscape architecture. In Biological Diversity and Conservation, vol. 1,2008 , no. 1, pp. 1-12.

JO, C. - SON, J.H. - SHIN, M.G. - BYUN, M.W. 2003. Irradiation effects on color and functional properties of persimmon (Diospyros kaki L. folium) leaf extract and licorice (Glycyrrhiza uralensis Fischer) root extract during storage. In Radiation Physics and Chemistry, vol. 67, 2003, no. 2, pp. 143-148. DOI: 10.1016/S0969-806X(02)00443-7

KANZAKI, S. - YONEMORI, K. - SATO, A. - YAMADA, M. - SUGIURA, A. 2000. Analysis of the genetic relationships among pollination-constant and non-astringent (PCNA) cultivars of persimmon (Diospyros kaki Thunb.) from Japan and China using amplified fragment length polymorphism (AFLP). In Journal of the Japanese Society for Horticultural Science, vol. 69, 2000, no. 6, pp. 665-670. DOI: $10.2503 /$ jjshs. 69.665

KHAN, S. - AL-QURAINY, F. 2009. Mutagenic effect of sodium azide on seed germination of Eruca sativa (L.). In Australian Journal of Basic and Applied Sciences, vol. 3, 2009, no. 4, pp. 3081-3087.

KHOSHBAKHT, K. - HAMMER, K. 2006. Savadkouh (Iran) an Evolutionary centre for fruit trees and shrubs. In $\mathrm{Ge}$ netic Resources and Crop Evolution, vol. 53, 2006, no. 3, pp. 641-651. DOI: 10.1007/s10722-005-7467-8

KIRUKI, S. - ONEK, L.A. - LIMO, M. 2006. Azide-based mutagenesis suppresses Striga hermonthica seed germination and parasitism on maize varieties. In African Journal of Biotechnology, vol. 5, 2006, no. 10, pp. 866-870. DOI: jb06156

LI, W. - OUYANG, Z. - MENG, X. - WANG, X. 2006. Plant species composition in relation to green cover configura-tion and function of urban parks in Beijing, China. In Ecological Research, vol. 21, 2006, no. 2, pp. 221-237. DOI: $10.1007 / \mathrm{s} 11284-005-0110-5$

LOIZZO, M.R. - SAID, A. - TUNDIS, R. - HAWAS, U.W. - RASHED, K. - MENICHINI, F. - FREGA, N.G. - ME-
NICHINI, F. 2009. Antioxidant and antiproliferative activity of Diospyros lotus L. extract and isolated compounds. In Plant Foods for Human Nutrition, vol. 64, 2009, no. 4, pp. 264-270. DOI: $10.1007 / \mathrm{s} 11130-009-0133-0$

LUO, Z.R. - YONEMORI, K. - SUGIURA, A. 1995. Evaluation of RAPD analysis for cultivar identification of persimmons (Diospyros kaki). In Journal of the Japanese Society for Horticultural Science, vol. 64, 1995, no. 3, pp. 535-541.

MAKI, S. - OYAMA, K. - KURAHASHI, T. - NAKAHIRA, T. - KAWABATA, T. - YAMADA, T. 2001. RFLP analysis for cultivar identification of persimmon. In Scientia Horticulturae, vol. 91, 2001, no. 3-4, pp. 407-412. DOI: 10.1016/ S0304-4238(01)00254-0

MESSAOUDI, Z. - GMILI, R.E. - KHATIB, F. - HELMY, Y. 2009. Effect of pollination, fruit thinning and gibberellic acid application on 'Fuyu' kaki fruit development. In Acta Horticulturae, 2009, no. 833, pp. 233-237.

MITCHELL, G.E. - MCLAUCHLAN, R.L. - ISAACS, A.R. - WILLIAMS, D.J. - NOTTINGHAM, S.M. 1992. Effect of low dose irradiation on composition of tropical fruits and vegetables. In Journal of Food Composition and Analysis, vol. 5, 1992, no. 4, pp. 291-311. DOI: 10.1016/08891575(92)90063-P

MOLINA-CANO, J.L. - SIMIAND, J.P. - SOPENA, A. - PEREZ-VANDRELL, A.M. - DORSCH, S. - RUBIALES, D. - SWANSTON, J.S. - JAHOOR, A. 2003. Mildew-resistant mutants induced in North American two- and six-rowed malting barley cultivars. In Theoretical and Applied Genetics, vol. 107, 2003, no. 7, pp. 1278-1287. DOI: 10.1007/ s00122-003-1362-5

NABAVI, S.M. - EBRAHIMZADEH, M.A. - NABAVI, S.F. - FAZELIAN, M. - ESLAMI, B. 2009. In vitro antioxidant and free radical scavenging activity of Diospyros lotus and Pyrus boissieriana growing in Iran. In Pharmacognosy Magazine, vol. 5, 2009, no. 18, pp. 122-126.

NAVAL, M.M. - ZURIAGA, E. - PECCHIOLI, S. - LLÁCER, G. - GIORDANI, E. - BADENES, M.L. 2010. Analysis of genetic diversity among persimmon cultivars using microsatellite markers. In Tree Genetics \& Genomes, vol. 6, 2012, no. 5, pp. 677-687. DOI: 10.1007/s11295-010-0283-0

OZEN, A. - COLAK, A. - DINCER, B. - GUNER, S. 2004. A diphenolase from persimmon fruits (Diospyros kaki L., Ebenaceae). In Food Chemistry, vol. 85, 2004, no. 3, pp. 431-437. DOI: 10.1016/j.foodchem.2003.07.022

PEARSON, O.W. - SANDER, C. - NILAN, R.A. 1975. The effect of sodium azide on cell processes in the embryonic barley shoot. In Radiation Botany, vol. 15, 1975, no. 4, pp. 315-322. DOI: 10.1016/0033-7560(75)90002-2

PRADO, M.J. - GONZALEZ, M.V. - ROMO, S. - HERRERA, M.T. 2007. Adventitious plant regeneration on leaf explants from adult male kiwifruit and AFLP analysis of genetic variation. In Plant Cell, Tissue and Organ Culture, vol. 88,2007 , no. 1 , pp. 1-10. DOI: 10.1007/s11240-0069116-0

PRINA, A.R. - FAVRET, E.A. 1983. Parabolic effect in sodium azide mutagenesis in barley. In Hereditas, vol. 98, 1983, no. 1, pp. 89-94. DOI: 10.1111/j.1605223.1983. tb00583.x

RINES, H.W. 1985. Sodium azide mutagenesis in diploid and hexaploid oats and comparison with ethyl methanesulfo- 
nate treatments. In Environmental and Experimental Botany, vol. 25, 1985, no. 1, pp. 7-16. DOI: 10.1016/00988472(85)90043-7

SAID, A. - HAWAS, U.W. - NOFAL, S.M. - RASHED, K. - HUEFNER, A. 2009. Pharmaco-chemical studies on the aqueous methanolic extract of Diospyros lotus leaves. In Research Journal of Phytochemistry, vol. 3, 2009, no. 1, pp. 1-12. DOI: 10.3923/rjphyto.2009.1.12

SAMADI, G.R. - MIAKHEL, I.M. - ABDIANI, S.A. 2009. Status of persimmon cultivation in Afghanistan. In Acta Horticulturae, 2009, no. 833, pp. 31-34.

SANDER, C. - MUEHLBAUER, F.J. 1977. Mutagenic effects of sodium azide and gamma irradiation in Pisum. In Environmental and Experimental Botany, vol. 17, 1977, no. 1, pp. 43-45. DOI: 10.1016/0098-8472(77)90019-3

STENLID, G. 1949. Some notes on the effect of sodium azide, 2,4-dimtrophenol, and ortho-phenanthroline upon oxygen consumption in green leaves. In Physiologia Plantarum, vol. 2, 1949, no. 1, pp. 61-69. DOI: 10.1111/j.1399. 3054.1949.tb07649.x

TAO, R. - GAO, M. - ESUMI, T. - KITAMURA, Y. YAMADA, A. 2009. High frequency ploidy variation observed in seedlings of a hexaploid persimmon cultivar 'Fujiwaragosho'. In Acta Horticulturae, 2009, no. 833, pp. $131-134$.

VELEMINSKY, J. - ANGELIS, K.J. 1987. Effects of sodium azide on replicative and repair DNA synthesis in barley embryos. In Mutation Research, vol. 190, 1987, pp. 125129. DOI: 10.1016/0165-7992(87)90043-1

VOS, P. - HOGERS, R. - BLEEKER, M. - REIJANS, M - LEE, T. - HORNES, M. - FRIJTERS, A. - POT, J. -
PELEMAN, J. - KUIPER, M. - ZABEAU, M. 1995. AFLP: a new technique for DNA fingerprinting. In Nucleid Acids Research, vol. 23, 1995, no. 21, pp. 4407-4414.

YAMAGISHI, M. - MATSUMOTO, S. - NAKATSUKA, A. - ITAMURA, H. 2005. Identification of persimmon (Diospyros kaki) cultivars and phenetic relationships between Diospyros species by more effective RAPD analysis. In Scientia Horticulturae, vol. 105, 2005, no. 2, pp. 283-290. DOI: 10.1016/j.scienta.2005.01.020

YAMANE, H. - ICHIKI, M. - TAO, R. - ESUMI, T. YONEMORI, K. 2009. Fruit growth and development of small-fruit dwarf mutant in Japanese persimmon (Diospyros kaki Thunb.). In Acta Horticulturae, 2009, no. 833, pp. 125-130.

YAMASAKI, H. - SAKIHAMA, Y. 2000. Simultaneous production of nitric oxide and peroxynitrite by plant nitrate reductase: in vitro evidence for the NR-dependent formation of active nitrogen species. In FEBS Letters, vol. 468, 2000, no. 1, pp. 89-92.

YONEMORI, K. - HONSHO, C. - KITAJIMA, A. - AKIRA, K. - ARADHYA, M. - GIORDANI, E. - BELLINI, E. PARFITT, D.E. 2008. Relationship of European persimmon (Diospyros kaki Thunb.) cultivars to Asian cultivars, characterized using AFLPs. In Genetic Resources and Crop Evolution, vol. 55, 2008, no. 1, pp. 81-89. DOI: 10.1007/ s10722-007-9216-7

Received: January, $31^{\text {th }}, 2012$ 